\title{
Ekstrak Daun Pisang Klutuk (Musa balbisiana Colla) sebagai Bahan Tambahan pada Pembuatan Kemasan Aktif berbasis Methyl Cellulose
}

\author{
Safinta Nurindra Rahmadhia a,1,*, Umar Santoso ${ }^{\text {b,c,2, }}{ }^{\text {, Supriyadi }}{ }^{\text {b,c,3 }}$ \\ ${ }^{a}$ Program Studi Teknologi Pangan, Fakultas Teknologi Industri, Universitas Ahmad Dahlan, Jl. Ringroad Selatan, Kragilan, Tamanan, Kec. Banguntapan, \\ Bantul, Daerah Istimewa Yogyakarta, Indonesia 55191 \\ ${ }^{\mathrm{b}}$ Departemen Teknologi Pangan dan Hasil Pertanian, Fakultas Teknologi Pertanian, Universitas Gadjah Mada, Jl. Flora Bulaksumur No.1, Kocoran, \\ Caturtunggal, Kec. Depok, Kabupaten Sleman, Daerah Istimewa Yogyakarta, Indonesia 55281 \\ ${ }^{\text {c }}$ Pusat Studi Pangan dan Gizi, Universitas Gadjah Mada, JL. Teknika Utara, Barek, Kocoran, Caturtunggal, Kec. Depok, Kabupaten Sleman, Daerah \\ Istimewa Yogyakarta, Indonesia 55281 \\ ${ }^{1}$ safinta.rahmadhia@tp.uad.ac.id *; ${ }^{2}$ umar_santoso@yahoo.com; ${ }^{3}$ suprif248@ugm.ac.id \\ * corresponding author
}

\section{ARTICLE INFO}

Article history

Received July 25, 2019

Revised September 17, 2019

Accepted September 19, 2019

Keywords

Banana leaf

Active packaging

Methyl cellulose

\section{ABSTRACT}

The packaging is important in our life. Banana leaf is one of the traditional packaging materials that is widely used because it has wide leaves and is not easily torn. However, traditional packaging has been abandoned by many people, so active packaging needs to be developed that has an advantage of modern and traditional packaging. In this study the active packaging was made based on methylcellulose (MC) which is added by klutuk banana leaf extract (EDPK) and glutaraldehyde (GA). EDPK studied its antioxidant properties and the active packaging was studied for its physical properties. Klutuk banana leaves dried using a cabinet dryer then mashed up and extracted by maceration method using $80 \%$ methanol and concentrated with a rotary vacuum evaporator. Then the extract was analyzed for its antioxidant properties. The active packaging/film prepared by casting with the addition of EDPK as an antioxidant and (GA) as a crosslinker agent. EDPK has antioxidant activity 33,17 $\pm 0,84 \%$ RSA, total phenolic 76,58 \pm 7,95 $\mathrm{mg} \mathrm{GAE} / \mathrm{g}$ EDPK and total flavonoids $29.52 \pm 4.01 \mathrm{mg}$ QE/g EDPK. The thickness of EDPK films ranged from 0,062-0,080 mm. The FTIR spectrum of EDPK films shows a relatively similar profile in all film formulations.

This is an open-access article under the CC-BY-SA license.

\section{Pendahuluan}

Kemasan merupakan suatu hal yang penting pada semua aspek kehidupan terutama pada bidang pangan. Kemasan berfungsi untuk membungkus makanan agar terhindar dari kotoran serta menambah daya tarik dari produk yang dikemasnya. Selain itu kemasan juga dapat digunakan untuk menampilkan informasi produk yang dikemas. Kemasan terbagi menjadi dua jenis yaitu kemasan modern dan kemasan tradisional. Kemasan modern berupa plastik, kardus maupun kemasan alumunium. Kemasan modern yang paling sering digunakan adalah kemasan dengan bahan dasar plastik karena mudah didapat dan praktis digunakan. Namun kemasan plastik memiliki suatu kekurangan yaitu bahannya yang tidak dapat didaur ulang. Kemasan tradisional dapat berupa daundaunan, batang pohon serta organ hewan seperti usus. Kemasan tradisional yang umum digunakan adalah daun seperti daun pisang, janur, daun jati, dan lain-lain. Salah satu daun yang paling sering digunakan adalah daun pisang. Daun pisang memiliki jenis yang beraneka ragam, namun hanya beberapa jenis saja yang lazim digunakan sebagai bahan pengemas seperti daun pisang Kepok, Klutuk dan Uter. Daun pisang klutuk banyak digunakan sebagai pengemas makanan karena memiliki struktur daun yang lebar dan kokoh sehingga tidak mudah robek jika digunakan. 
Penggunaan bahan pengemas makanan umumnya digunakan secara langsung bersentuhan dengan makanan yang dikemas. Bahan pangan atau olahan pangan yang dikemas secara kontak langsung dengan bahan pengemasnya dapat mengakibatkan adanya migrasi senyawa kimia ke dalam produk yang dikemas [1]. Oleh karena itu senyawa kimia pada daun pisang dapat bermigrasi ke dalam makanan jika dikemas dengannya. Daun pisang memiliki aktivitas antioksidan dan antimikrobia. Senyawa antioksidan yang terdapat dalam ekstrak daun pisang diantaranya adalah asam galat yang merupakan golongan dari katekin. Katekin termasuk ke dalam golongan polifenol [2]. Phenol, 2,4-bis(1,1-dimethylethyl) merupakan seyawa dominan yang terdapat pada ekstrak metahol dari daun pisang klutuk [3]. Senyawa Phenol, 2,4-bis(1,1-dimethylethyl) merupakan senyawa fenolik yang berpotensi sebagai antioksidan dan antimikrobia [4]. Pada fraksi ethyl asetat daun dewa Gynura sagentum diketahui adanya senyawa Phenol, 2,4-bis(1,1-dimethylethyl) dan E-15 heptadecenal yang berkontribusi pada aktivitas antimikrobia [5].

Pengemas tradisional telah banyak ditinggalkan oleh masyarakat karena dinilai tidak praktis dan sulit didapatkan. Masyarakat lebih menyukai kemasan plastik karna lebih praktis, murah dan mudah didapatkan. Namun plastik tidak memiliki flavor dan senyawa kimia seperti antioksidan dan antimikrobia. Untuk mengatasi hal tersebut telah banyak dikembangkan kemasan dengan bahan polimer alami atau biopolimer sehingga kemasan tersebut dapat terdegradasi serta mudah digunakan. Maka perlu dikembangkan kemasan aktif dengan bahan dasar biopolimer.

Sistem kemasan aktif didasarkan pada bahan kemasan yang ditambahkan zat aditif dengan sifat antioksidan dan atau antimikrobia yang bertujuan untuk memperpanjang umur simpan dan meningkatkan kualitas makanan yang dikemasnya [6-9]. Zat aktif yang ditambahkan ke dalam matriks polimer akan bermigrasi ke dalam makanan yang dikemas sehingga akan memperpanjang umur simpannya. Oleh karena itu perlu dikembangkan kemasan aktif dengan penambahan zat antioksidan atau antimikrobia. Penelitian ini dilakukan untuk menambahkan EDPK sebagai zat antioksidan ke dalam kemasan berbasis MC untuk meningkatkan sifat fungsionalnya.

\section{Metodologi}

\subsection{Alat dan Bahan}

Alat yang digunakan pada penelitian ini yaitu Cabinet dryer (EYELA NDS-60 1D; Japan), Rotary vacuum evaporator (IKA RV 06-ML 1-B), Spectrofotometer UV-VIS (Spectonic 200) dan Spectrofotometer Infrared (IRPRESTIGE-21 SHIMADZU). Bahan yang digunakan adalah daun pisang klutuk dari kebun pisang di Gamping DIY, Methyl cellulose (Sigma Aldrich, USA), Glutaraldehyde, Polyethylene Glycol 400 (Merck, USA), 2,2-diphenyl-1-picrylhydrazyl (DPPH), Asam galat, Quercetin, dan Folin Ciocalteu.

\subsection{Ekstraksi Daun Pisang Klutuk}

Pembuatan EDPK berdasarkan metode [3]. Daun pisang yang telah dibersihkan dengan air mengalir kemudian dipotong-potong dan dikeringkan dengan menggunakan cabinet dryer. Pengeringan dilakukan selama 24 jam pada suhu $50{ }^{\circ} \mathrm{C}$. Daun pisang kering dihaluskan menggunakan blender dan diayak hingga berukuran 60 mesh.

Proses ekstraksi dilakukan dengan metode maserasi menggunakan metanol $80 \%$ selama 48 jam. Sebanyak $100 \mathrm{~g}$ bubuk daun pisang klutuk direndam dalam $800 \mathrm{ml}$ metanol $80 \%$. Supernatan dari hasil maserasi kemudian dipekatkan dengan rotary vacuum evaporator pada suhu $40{ }^{\circ} \mathrm{C}$.

\subsection{Analisa Ekstrak Daun Pisang Klutuk}

EDPK dianalisa antioksidan, total fenolik dan total flavonoidnya. Nilai antioksidan dalam EDPK dianalisa berdasarkan metode [10] menggunakan 2,2-diphenyl-1-picrylhydrazyl (DPPH). Nilai total fenolik dianalisa dengan berdasarkan metode [11] menggunakan folin ciocalteu. Larutan standar yang digunakan untuk kurva kalibrasi adalah asam galat. Analisa nilai total flavonoid berdasarkan metode [12]. Standar yang digunakan untuk menentukan total flavonoid adalah quercetin. Analisa total antioksidan, total fenolik dan total flavonoid diukur absorbansinya pada panjang gelombang masing-masing $515 \mathrm{~nm}, 760 \mathrm{~nm}$ dan $510 \mathrm{~nm}$ menggunakan Spectrofotometer Infrared. 


\subsection{Pembuatan Kemasan Aktif}

Pembuatan kemasan aktif menggunakan metode casting menurut [13-14] dengan modifikasi. Kemasan aktif yang dibuat menggunakan MC sebagai bahan utama. MC dilarutkan dalam etanol $70 \%$ pada suhu $70{ }^{\circ} \mathrm{C}$ selama 1 jam. Kemudian ditambahkan glutaraldehyde 15,30 dan $45 \%$ (b/b) sebagai agen croslinking. Penambahan EDPK 50.000 ppm sebanyak 5, 10 dan 15\% (v/v) dilakukan setelah suhu larutan mencapai $40{ }^{\circ} \mathrm{C}$. Kemudian larutan dicetak menggunakan nampan kaca dan dikeringkan menggunakan cabinet dryer suhu $50^{\circ} \mathrm{C}$ selama 12 jam.

\subsection{Analisa Kemasan Aktif}

Pada kemasan aktif dianalisa ketebalan dan fourier transform infrared spectroscopy (FTIR). Ketebalan film/kemasan aktif ekstrak daun pisang klutuk diukur menggunakan mikrometer digital pada 5 titik secara acak. Pengukuran ketebalan dilakukan dalam tiga kali pengulangan. FTIR digunakan untuk mengkarakterisasi keberadaan gugus kimia spesifik pada bahan dan untuk melihat efisiensi dari proses crosslinking. Film MC dianalisa dengan Spectrofotometer Infrared (IRPRESTIGE-21 SHIMADZU) menggunakan mode transmitansi.

\section{Hasil dan Pembahasan}

\subsection{Ekstrak Daun Pisang Klutuk}

Analisa antioksidan pada EDPK dilakukan untuk mengamati potensi antioksidan dari daun pisang klutuk yang digunakan. Aktivitas antioksidan EDPK dibandingkan dengan antioksidan sintesis yaitu BHT. Hasil analisa antioksidan pada EDPK dapat dilihat pada Tabel 1.

Tabel 1. Nilai aktivitas antioksidan, total fenolik dan total flavonoid ekstrak daun pisang klutuk.

\begin{tabular}{ll}
\hline \multicolumn{1}{c}{ Analisa } & \multicolumn{1}{c}{ Hasil } \\
\hline Aktivitas Antioksidan Ekstrak DPK & $33,17 \pm 0,84 \% \mathrm{RSA}$ \\
Aktivitas Antioksidan BHT & $64,04 \pm 0,44 \% \mathrm{RSA}$ \\
Total Fenolik & $76,58 \pm 7,95 \mathrm{mg} \mathrm{GAE} / \mathrm{g}$ ekstrak DPK \\
Total Flavonoid & $29,52 \pm 4,01 \mathrm{mg} \mathrm{QE} / \mathrm{g}$ ekstrak DPK \\
\hline
\end{tabular}

Senyawa antioksidan dapat mengalami kerusakan akibat adanya pengolahan. Proses pengeringan dengan waktu lebih dari 7 jam akan banyak menghilangkan senyawa antioksidan dalam bahan [15]. Proses pengeringan daun pisang klutuk dilakukan selama 24 jam pada suhu $50{ }^{\circ} \mathrm{C}$. Dengan proses pengeringan yang cukup lama, EDPK memiliki aktivitas antioksidan 33,17 $\pm 0,84 \%$ pada konsentrasi ekstrak $0,1 \mathrm{~g} / 100 \mathrm{ml}$. Nilai tersebut cukup rendah jika dibandingkan dengan aktivitas antioksidan BHT, yaitu $66,04 \pm 0,44 \%$ pada konsentrasi BHT 0,01 g/100 ml. Pada penelitiannya [3] menyebutkan bahwa aktivitas antioksidan EDPK sebesar 4,74\% RSA pada konsentrasi 0,01 g/100 ml. Berdasarkan data tersebut, dapat dikatakan bahwa nilai aktivitas antioksidan EDPK juga dipengaruhi oleh asal dari pohon pisang klutuk yang digunakan.

Seperti halnya aktivitas antioksidan, komponen fenolik pada bahan juga dipengaruhi oleh waktu dan suhu pengeringan. Selain itu hal penting yang juga memengaruhi jumlah komponen fenolik pada bahan adalah pelarut yang digunakan pada saat ekstraksi dan proses ekstraksi. Daun pisang ambon yang dikeringkan pada suhu $60{ }^{\circ} \mathrm{C}$ memiliki nilai total fenolik yang lebih besar dari daun yang dikeringkan pada suhu $40{ }^{\circ} \mathrm{C}$ dan $50{ }^{\circ} \mathrm{C}$ [16]. Hal tersebut dapat disebabkan oleh komponen fenolik yang berikatan dengan komponen daun lainnya seperti protein dan atau dikarenakan adanya perubahan struktur kimia pada saat proses pengeringan [17].

Sama seperti nilai total fenolik, nilai total flavonoid pada suatu bahan juga dipengaruhi oleh waktu dan suhu pengeringan serta pelarut yang digunakan. Pada penelitian ini didapatkan nilai total flavonoid EDPK sebesar 29,52 \pm 4,01 mg QE/g ekstrak (Tabel 1.).

\subsection{Ketebalan Film}

Ketebalan film EDPK berkisar antara 0,062 - 0,080 mm seperti pada Tabel 2. Ketebalan film dipengaruhi oleh banyaknya EDPK dan GA yang diberikan pada saat pembuatan film. Film dengan pemberian ekstrak paling banyak memiliki ketebalan yang paling rendah. Hal tersebut bertentangan dengan penelitian yang dilakukan oleh [18] yang mengatakan bahwa ketebalan film meningkat 
seiring dengan kenaikan jumlah mineral dan vitamin $\mathrm{E}$ yang ditambahkan pada film berbasis chitosan. Sifat polimer pembentuk film dan zat aditif memengaruhi ketebalan film karena adanya interaksi dengan matriks polimer [19].

Pada saat proses pelarutan MC dengan etanol $70 \%$ menggunakan suhu panas hingga mencapai $70{ }^{\circ} \mathrm{C}$ selama 1 jam. Proses pemanasan tersebut dapat menghilangkan sebagian pelarut dikarenakan kondisi pelarut yang polar sehingga dapat menguap selama proses pemanasan tersebut. Oleh karena menguapnya sebagian pelarut pada saat proses pemanasan menyebabkan volume larutan MC menjadi berbeda-beda pada tiap pembuatan sampel. Volume yang berbeda tersebut menyebabkan ketebalan film pada saat proses pencetakan juga berbeda.

Tabel 2. Ketebalan dan warna film berbasis methyl cellulose dengan penambahan glutaraldehyde dan ekstrak daun pisang klutuk pada berbagai variasi.

\begin{tabular}{llllll}
\hline \multicolumn{1}{c}{ Sampel } & \multirow{2}{*}{ Ketebalan $(\mathbf{c m})$} & Sampel & Ketebalan $(\mathbf{c m})$ & Sampel & \multirow{2}{*}{ Ketebalan $(\mathbf{c m})$} \\
\hline DP5_GA0 & $0,077 \pm 0,000^{\mathrm{c} 2}$ & DP10_GA0 & $0,068 \pm 0,001^{\mathrm{b} 2}$ & DP15_GA0 & $0,063 \pm 0,000^{\mathrm{a} 2}$ \\
DP5_GA15 & $0,076 \pm 0,001^{\mathrm{c} 4}$ & DP10_GA15 & $0,071 \pm 0,001^{\mathrm{b} 4}$ & DP15_GA15 & $0,080 \pm 0,001^{\mathrm{a} 4}$ \\
DP5_GA30 & $0,067 \pm 0,000^{\mathrm{c} 1}$ & DP10_GA30 & $0,066 \pm 0,001^{\mathrm{b} 1}$ & DP15_GA30 & $0,062 \pm 0,000^{\mathrm{a} 1}$ \\
DP5_GA45 & $0,071 \pm 0,000^{\mathrm{c} 3}$ & DP10_GA45 & $0,078 \pm 0,001^{\mathrm{b} 3}$ & DP15_GA45 & $0,073 \pm 0,000^{\mathrm{a} 3}$ \\
\hline
\end{tabular}

a. Simbol huruf menunjukkan perbedaan signifikansi ekstrak daun pisang klutuk (DP) $(p<0,05)$ pada kolom yang sama.

1. Simbol angka menunjukkan perbedaan signifikansi glutaraldehyde (GA) $(p<0,05)$ pada kolom yang sama.

\subsection{Fourier Transform Infrared Spectroscopy (FTIR)}

Analisa FTIR dilakukan pada semua sampel perlakuan dan dibandingkan dengan sampel kontrol berupa film MC. Pada Gambar 1, 2 dan 3 menunjukkan spektrum FTIR dari film EDPK pada berbagai konsentrasi penambahan ekstrak dan GA. Pada gambar tersebut dapat dilihat bahwa berbagai formulasi film EDPK, semuanya memiliki spektrum FTIR yang sama dikarenakan oleh struktur kimia yang sama. Gambar 4 menunjukkan spektrum FTIR dari MC tanpa penambahan apapun. Menurut [20] fitur yang paling relevan untuk spektrum MC adalah pita peregangan $\mathrm{O}-\mathrm{H}$ (3000 - $3700 \mathrm{~cm}^{-1}$ ), pita peregangan C-H $2837 \mathrm{~cm}^{-1}$, pita peregangan C-O $1643 \mathrm{~cm}^{-1}$ dari glukosa pada selulosa dan peregangan cincin pada $896 \mathrm{~cm}^{-1}$.

Spektrum FTIR untuk MC pada penelitian ini memiliki peak yang sama dengan peak spektrum FTIR MC yang dimiliki [20] yaitu $3448,72 \mathrm{~cm}^{-1}$ untuk gugus $\mathrm{O}-\mathrm{H}, 2839,22 \mathrm{~cm}^{-1}$ untuk gugus $\mathrm{C}-\mathrm{H}$ dan $1643,55 \mathrm{~cm}^{-1}$ untuk gugus C-O. Struktur MC disusun oleh rantai linear dengan ikatan $\beta-(1 \rightarrow 4)$ dengan satu gugus $-\mathrm{OH}$ bebas dan dua gugus $-\mathrm{OCH}_{3}$ tiap unit. Karena ikatan $\beta$-, unit methylated glucose dapat dibalik, meningkatkan ranting intra dan inter ikatan hidrogen dan dapat bereaksi dengan agen crosslinker. Gugus aldehid dari molekul GA dan gugus hidroksil dari rantai polimer MC telah diverifikasi dengan adanya puncak baru, seperti puncak pada 1163 dan $2860 \mathrm{~cm}^{-1}$ (masingmasing $\mathrm{C}-\mathrm{O}$ dan $-\mathrm{CH}_{2}$ - dalam ikatan crosslingking hemi-acetal) [21].

Pada penelitian ini, spektrum FTIR dari film EDPK tidak menunjukkan adanya peak 1163 dan $2860 \mathrm{~cm}^{-1}$ dikarenakan formula film yang sangat kompleks. Hal ini juga terjadi pada penelitian [13] dimana tidak terdapat peak 1163 dan $2860 \mathrm{~cm}^{-1}$. Spektrum pada semua formulasi film EDPK menunjukkan puncak yang tidak sama namun mirip dengan puncak pada film MC. Hal itu dapat dimungkinkan karena adanya crosslinking antara gugus MC dengan formula film lainnya seperti EDPK, GA atau PEG. 

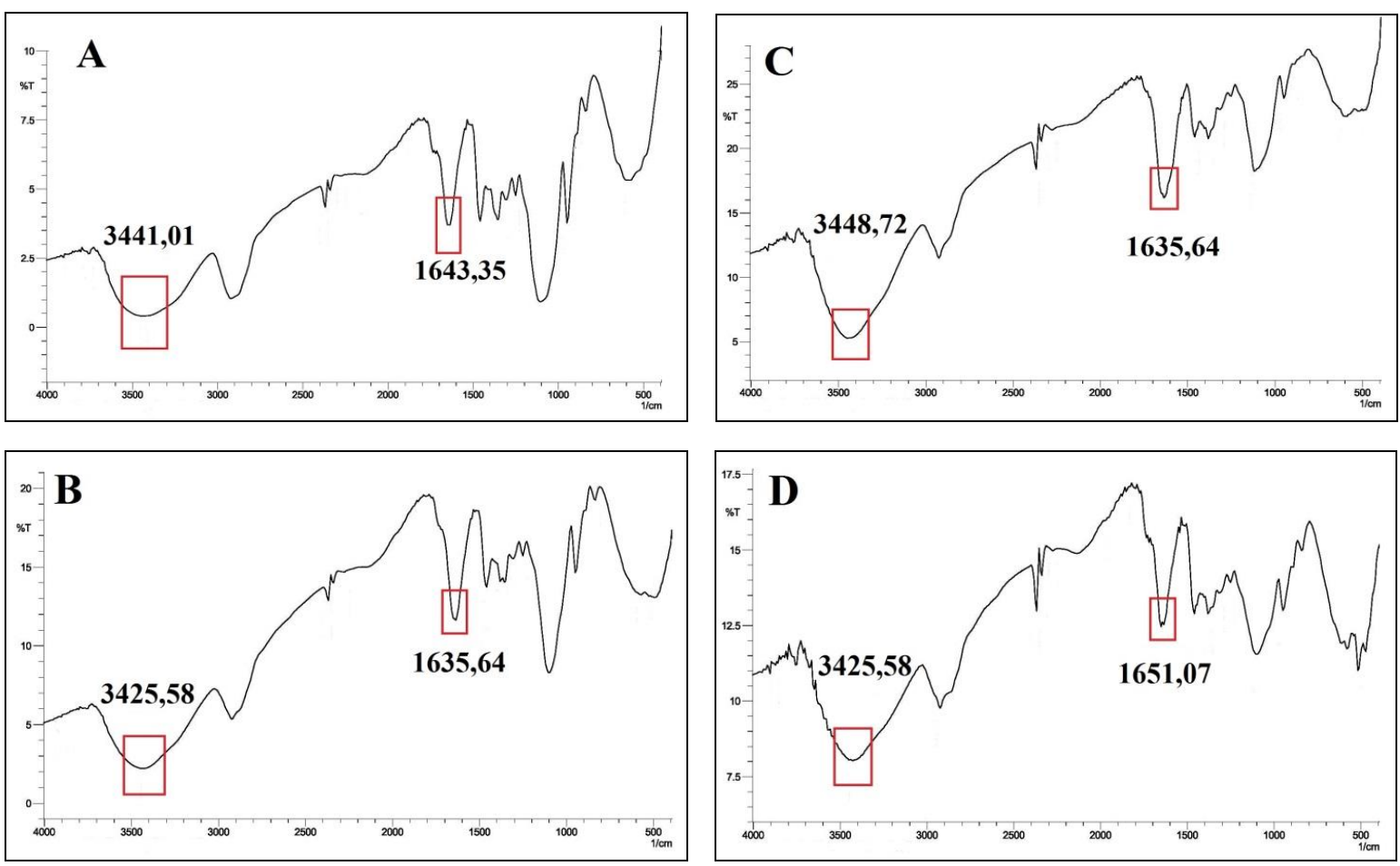

Gambar 1. FTIR film ektrak daun pisang klutuk (EDPK). (A) MC_DP5_GA0 (B) MC_DP5_GA15 (C) MC_DP5_GA30 (D) MC_DP5_GA45.
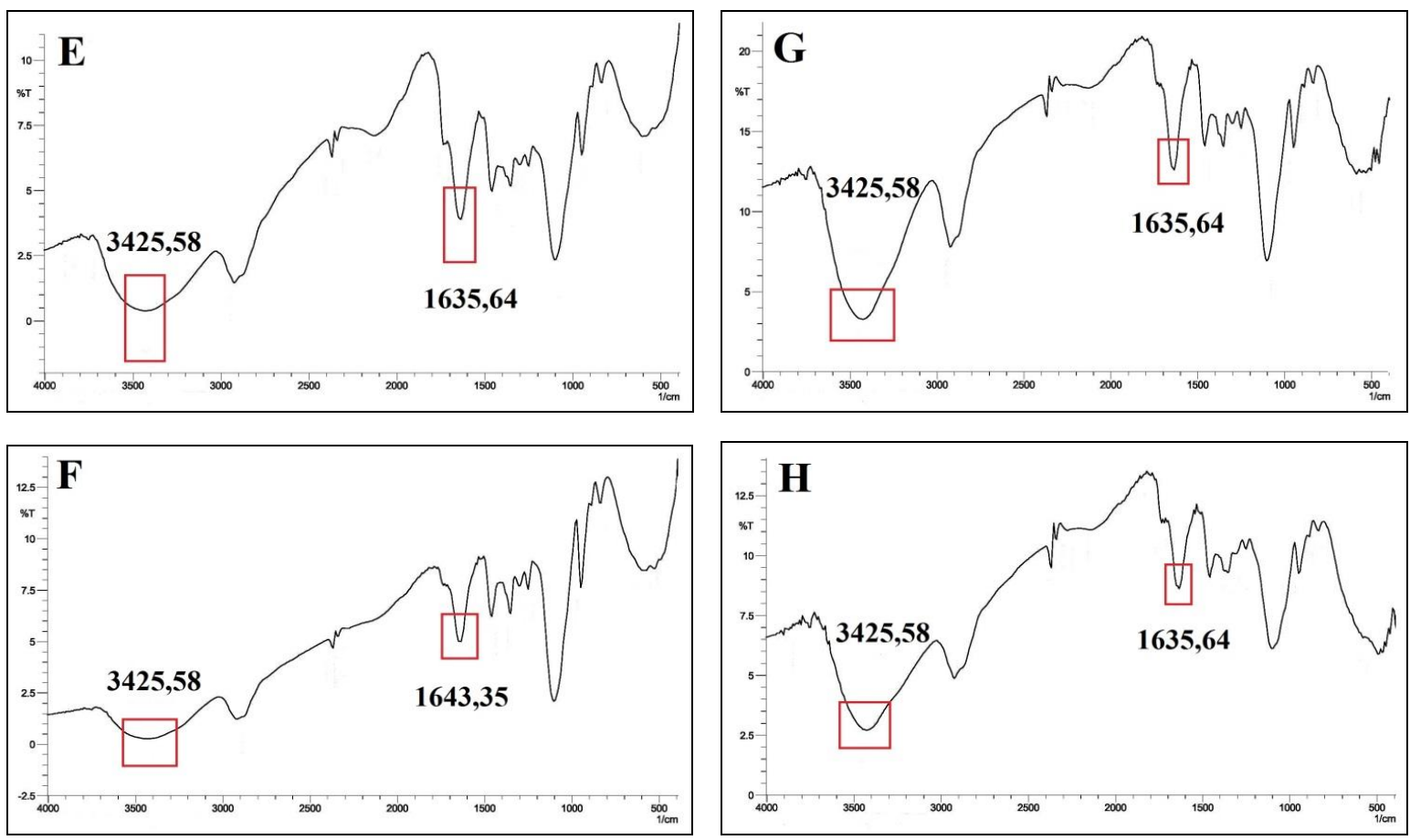

Gambar 2. FTIR film ekstrak daun pisang klutuk (EDPK). (E) MC_DP10_GA0 (F) MC_DP10_GA15 (G) MC_DP10_GA30 (H) MC_DP10_GA45. 

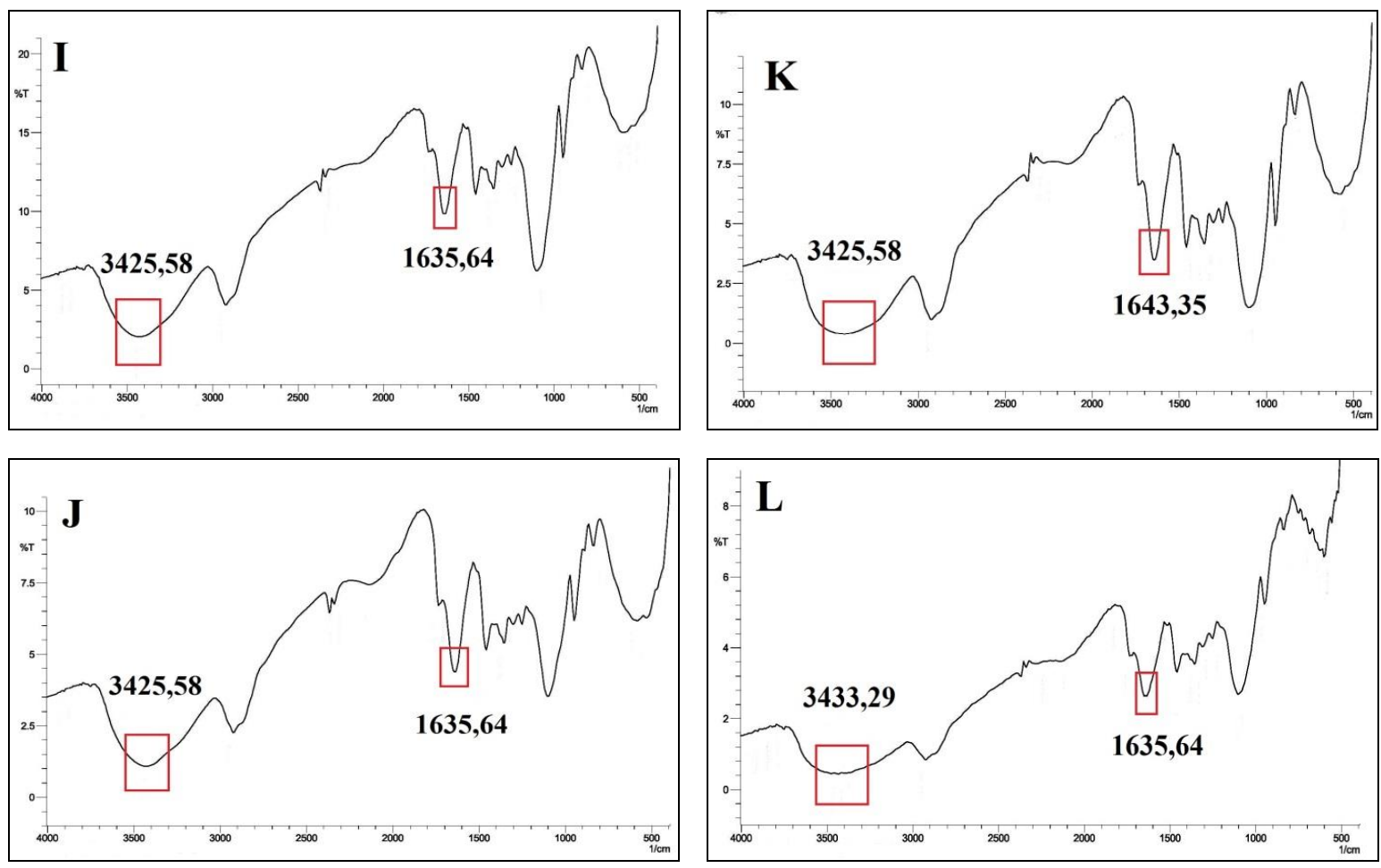

Gambar 3. FTIR film ekstrak daun pisang klutuk (EDPK). (I) MC_DP15_GA0 (J) MC_DP15_GA15 (K) MC_DP15_GA30 (L) MC_DP15_GA45.

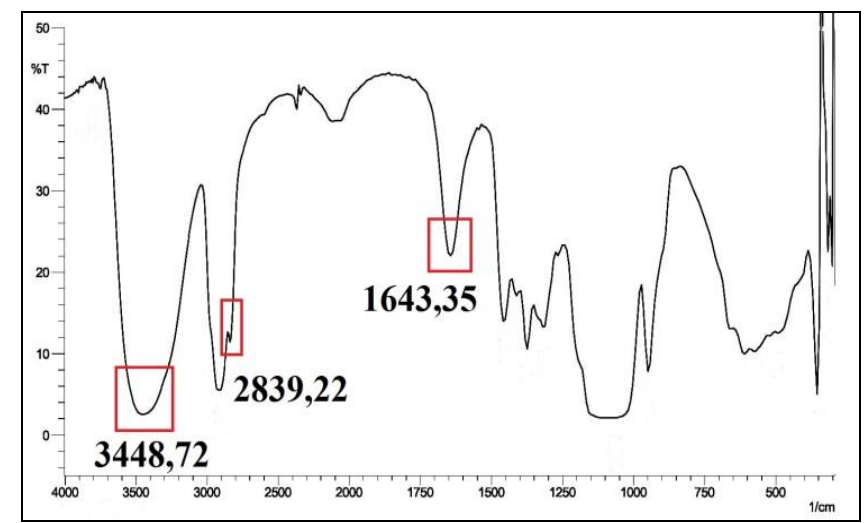

Gambar 4. FTIR film methyl cellulose.

\section{Kesimpulan}

Berdasarkan penelitian yang telah dilakukan, dapat disimpulkan bahwa EDPK memiliki senyawa antioksidan dilihat dari nilai aktivitas antioksidan, total fenolik dan total flavonoid sehingga dapat meningkatkan sifat fungsional kemasan aktif jika ditambahkan kedalamnya. Ketebalan film EDPK dipengaruhi oleh volume larutan yang akan dicetak. Spektrum FTIR pada semua film EDPK menunjukkan pola yang sama dengan spektrum pada film MC pada titik tertentu.

\section{Ucapan Terimakasih}

Terimakasih kepada Kementrian Riset Teknologi dan Pendidikan Tinggi (Kemenristek Dikti) melalui program hibah Penelitian Unggulan Perguruan Tinggi (PUPT) tahun anggaran 2016 yang telah mendanai penelitian ini. 


\section{Daftar Pustaka}

[1] Castle, L. An introduction to chemical migration from food contact materials. New York: DEFRA Central Science Laboratory. 2000.

[2] Sahaa, R.K., Srijan A., Syed Sohidul H.S., dan Priyanka R. Medicinal activities of the leaves of Musa sapientum var. sylvesteris in vitro. Asian Pacific Journal of Tropical Biomedicine. 2013; 3(6): 476-482.

[3] Fitriani, V. Tesis, Karakter fisik dan kimia serta identifikasi senyawa bioaktif dari daun pisang klutuk (musa bracycarpa) sebagai bahan pengemas makanan. 2016. Fakultas Teknologi Pertanian, Universitas Gadjah Mada Yogyakarta.

[4] Handayani, R dan Mastuti,T.S. Senyawa penyusun ekstrak N-heksana dari daun pisang batu, kepok dan ambon hasil distilasi air. Prosiding Seminar Nasional Sains dan Teknologi, Universitas Wahid Hasyim. 2013; 5: 60-64.

[5] Seow, L.j., Beh, H.K., Ibrahim, P., Sadikun, A. Dan Asmawi, Z. Antimicrobial activity of Gynura sagentum's leaf extracts and its active fraction. Tang International Journal of Genuine Traditional Medicine. 2012; 2: 115 - 123.

[6] Vermeiren, L., Devlieghree, F. dan Debevere, J. Evaluation of meat born lactic acid bacteria as protective cultures for the biopreservation of cooked meat product. International Journal of Food Microbiology. 2004; 96(2): 149-164.

[7] Alvarez, M.F. Revision: envasado activo de los alimentos / review: active food packaging. Food Science and Technology International. 2000; 6(2): 97-108.

[8] Appendini, P. dan Hotchkiss, J.H. Review of antimicrobial food packaging. Innovative Food Science and Emerging Technologies. 2002; 3(2): 113-126.

[9] Del Nobile, M. A., Conte, A., Buonocore, G. G., Incoronato, A. L., Massaro, A., dan Panza, O. Active packaging by extrusion processing of recyclable and biodegradable polymers. Journal of Food Engineering. 2009; 93(1): 1-6.

[10]Williams, W.B., Cuvelier, M.E., dan Berset, C. Use of free radical method to evaluate antioxidant activity. Lebensm-Wiss-U-Technology. 1995; 28(1): 25-30.

[11] Singleton, V. L., Orthofer, R., dan Lamuela-Raventós, R. M. Analysis of total phenols and other oxidation substrates and antioxidants by means of Folin-Ciocalteu reagent. Methods in Enzymology. 1999; 299: 152-178.

[12]Roy, M.K., Juneja, L.R., Isobe, S., dan Tsushida, T. Steam processed broccoli (brassica oleracea) has higher antioxidant activity in chemical and cellular assay systems. Journal Food Chemidtry. 2009; 114(1): 263-269.

[13]Dicastillo, C.L., Rodriguez, F., Guarda, A., dan Galotto, M.J. Antioxidant films based on cross-linked methyl cellulose and native chilean berry for food packaging applications. Journal of Carbohydrate Polymers. 2015; 136: 1052-1060.

[14]Dicastillo, C.L., Bustos, F., Guarda, A., dan Galotto, M.J. Cross-linked methyl cellulose films with murta fruit extract for antioxidant and antimicrobial active food packaging. Journal of Food Hydrocolloids. 2016; 60: 335-344.

[15] Wojdyto, A., Figiel, A., dan Oszmianski, J. Influence of temperature and time of apple drying on phenolic compounds content and their antioxidant activity. Polish Journal Food Nutrition Science. 2007; 57(4): 601-605.

[16] Sagrin, M.S., dan Chong, G.H. Effect of drying temperature on the chemical and physical properties of musa acuminata colla (aaa group) leaves. Journal Industrial Crops and Products. 2013; 45: 430-434.

[17] Qu, W., Pan, Z., dan Ma, H. Extraction modeling and activities of antioxidants from pomegranate marc. Journal Food Engineering. 2010; 99(1): 16-23.

[18]Park, S. dan Zhao, Y. Incorporation of a high concentration of mineral or vitamin into chitosan-based films. Journal of Agricultural and Food Chemistry. 2004; 52(7): 1933-1939. 
[19] Salmieri, S. dan Lacroix, M. Physicochemical properties of alginate/polycaprolactone-based films containing essential oils. Journal of Agricultural and Food Chemistry. 2006; 54(26): 10205-10214.

[20] Wang, X.L., Yang, K.K., Wang, Y.Z., Wang, D.Y., dan Yang, Z. Cristallization and morphology of a novel biodegradable polymer system: poly(1,4-dioxan-2-one)/starch blend. Acta Materialia. 2004; 52(16): 4899-4905.

[21] Rimdusit, S., Somsaeng, K., Kewsuwan, P., Jubsilp, C., dan Tiptipakorn, S. Biodegradability and property characterization of methyl cellulose: effect of nanocompositing and chemical crosslingking. Carbohydrate Polymers. 2008; 72(3): $444-445$. 